\title{
RAD9A wt Allele
}

National Cancer Institute

\section{Source}

National Cancer Institute. RAD9A wt Allele. NCI Thesaurus. Code C106278.

Human RAD9A wild-type allele is located within 11q13.1-q13.2 and is approximately $7 \mathrm{~kb}$ in length. This allele, which encodes cell cycle checkpoint control protein RAD9A, is involved in the regulation of both DNA repair and cell cycle progression. 